\title{
役員会／委員会 名簿
}

\section{役員会}

部門長
編修長
副部門長
総務企画担当
会計担当
編修担当
研究調査担当
監事
委員 (技術者教育担当)
(国際活動担当)
(HP 担当)
(HP 担当)

\section{研究調查運営委員会}

$\begin{array}{ll}\text { 委員長 } & \text { 中川 活三（日本大学） } \\ \text { 副委員長 } & \text { 加藤 景三 (新潟大学) } \\ & \text { 高橋 俊裕 (電力中央研究所) } \\ \text { 大委員 } & \text { 昭仁 (日本大学) } \\ & \text { 相知 政司 (千葉工業大学) } \\ & \text { 草場 光博 (大阪産業大学) } \\ & \text { 熊田亜紀子 (東京大学) } \\ & \text { 後藤 啓次 (防衛大学校) } \\ & \text { 高木 浩一 (岩手大学) } \\ & \text { 早川 直樹 (名古屋大学) } \\ & \text { 日高 邦彦 (東京大学) } \\ & \text { 八島 政史 (東北大学) } \\ & \text { 山口 正洋 (東北大学) } \\ & \text { 山崎 健一 (電力中央研究所) } \\ \text { 吉川 信行 (横浜国立大学) }\end{array}$

\section{編修委員会}

\section{委員長}

副委員長

委員
西川 宏之（芝浦工業大学）

永田 正義（兵庫県立大学）

中川 活二（日本大学）

武藤 浩隆 (三菱電機)

保科 好一（東芝）

山城 啓輔 (富士電機)

楠川 順平（日立製作所）

藏田 保幸 (明電舎)

前山 光明 (埼玉大学)

加藤 景三（新潟大学）

高橋 俊裕（電力中央研究所）

匹田 政幸 (九州工業大学)

高木 浩一（岩手大学）

篠田 之孝（日本大学）

三宅 弘晃（東京都市大学）

井堀 春生（愛媛大学）

小迫 雅裕 (九州工業大学)
小田 昭紀 (千葉工業大学)
幹事

\section{論文委員会}

編修長

編修長補佐

〈A1グループ (共通) >

主査

副主査

幹事

永田 正義（兵庫県立大学）

菊池 祐介（兵庫県立大学）

相知 政司（千葉工業大学）

米津 大吾 (関西大学)

篠田 之孝（日本大学）

柴崎 年彦（東京都立産業技術

専門学校)

高原 健爾（福岡工業大学）

田中 久弥 (工学院大学)

27 人

〈A2グループ (基礎) >

主査

副主査

幹事

下村 直行 (徳島大学)

古川 静枝 (電力中央研究所)

猪原 哲（佐賀大学）

江角 直道（筑波大学）

王 斗艶（熊本大学）

大津 康徳（佐賀大学）

小島 寛樹 (名古屋大学)

八木澤 卓 (東芝メモリ)

126 人

<A3グル一プ (材料) >

主査

副主査

幹事
宮崎尚（防衛大学校）

中野 正基（長崎大学）

小野田光宜 (兵庫県立大学)

栗本 宗明（名古屋大学）

小迫 雅裕（九州工業大学）

曽根原 誠（信州大学）

遠山 和之（沼津工業高等

専門学校)

布施 則一（電力中央研究所）

山口広 (JFE スチール)

古川 静枝（電力中央研究所）

中野 正基（長崎大学）

石川 洋平（有明工業高等

専門学校)

尾崎 亮介（日本大学） 